\title{
Use of Immune Crops as Barrier in the Management of Cacao Swollen Shoot Virus Disease (CSSVD)-Long-Term Assessment
}

\author{
O. Domfeh, G. A. Ameyaw, H. K. Dzahini-Obiatey, L. A. A. Ollennu, K. Osei-Bonsu, K. Acheampong, F. Aneani, and F. Owusu-Ansah, \\ Cocoa Research Institute of Ghana, New Tafo-Akim, Eastern Region, Ghana
}

\begin{abstract}
Domfeh, O., Ameyaw, G. A., Dzahini-Obiatey, H. K., Ollennu, L. A. A., Osei-Bonsu, K., Acheampong, K., Aneani, F., and Owusu-Ansah, F. 2016. Use of immune crops as barrier in the management of cacao swollen shoot virus Disease (CSSVD)—Long-term assessment. Plant Dis. 100:1889-1893.

A field trial was conducted at the Cocoa Research Institute of Ghana from 1992 to 2004 to investigate the prospects of using Cacao swollen shoot virus (CSSV)-immune crops as a barrier to prevent the spread of the virus from existing outbreaks into newly established cacao plantings. The treatments consisted of four crops-citrus (Citrus spp.), oil palm (Elaeis guineensis Jacq.), kola (Cola nitida Vent.), and cacao (Theobroma cacao L.) - planted as a barrier between cacao trees serving as test plants on one side and as source of CSSV strain 1A infection on the other. Over a 7-year period post CSSV 1A inoculation, the citrus and oil palm barriers were the most effective in protecting test cacao trees from cacao swollen

shoot virus disease (CSSVD) spread. The two crops gave comparable results $(P=0.9766)$ in terms of the cumulative number of visibly infected trees ( 1 and 5 of 522, respectively). The kola barrier, on the other hand, had a significantly $(P<0.0001)$ higher number of symptomatic trees $(89$ of 522) than citrus and oil palm. All three crops (citrus, oil palm, and kola) provided better protection than the control (cacao), which had 134 visibly infected trees out of 522. As shown by economic analyses, growing citrus, oil palm, or kola as barrier crops was as profitable as growing cacao. The implications of the results on the management of CSSVD in Ghana are discussed.
\end{abstract}

Cacao swollen shoot virus disease (CSSVD), mainly confined to West Africa, is one of the major diseases limiting cacao (Theobroma cacao L.) production. Transmitted by mealybugs, CSSVD was first discovered in the Eastern Region of Ghana in 1936 (Steven 1936). In all, 18 species of mealybugs are known to transmit Cacao swollen shoot virus (CSSV) (Roivainen 1976) but, in Ghana, Formicococcus njalensis (Laing) and Planococcus citri (Risso) are the dominant and most important species. Altogether, these species account for nearly $90 \%$ of the total mealybug population on cacao (Bigger 1981; Campbell 1983). Typical symptoms of CSSVD include red vein banding, leaf chlorosis, stem swellings, reduced growth and vigor, dieback of branches, and death of plants (Crowdy and Posnette 1947; Posnette 1951).

The spread of CSSV occurs mainly through mealybugs feeding in interlocking branches of adjoining cacao trees as they move from tree to tree (Cornwell 1960; Thresh et al. 1988). Virus-carrying mealybugs may occasionally be blown by the wind or they may be carried by attendant ants (Crematogaster and Camponotus spp.) to cause an outbreak far from the original source of infection (Cornwell 1960; Ollennu et al. 1989; Strickland 1950). Described as "jump spread", this route of spread appears to be relatively infrequent (Posnette 1943; Thresh 1958). Swollen shoot outbreaks tend to occur around existing ones and then spread to give clearly defined expanding foci, which eventually coalesce to form larger areas of mass infections (Thresh et al. 1988).

The basic method of controlling CSSV, like other vector-borne tree viruses, is by removing visibly infected trees and their neighboring "contacts" (eradication) (Thresh and Owusu 1986). Various eradication schemes have been implemented in Ghana since 1936 but these have suffered serious socioeconomic and political setbacks, resulting in the inability to adequately control the disease (Ameyaw et al. 2014; Owusu 1983; Owusu et al. 1996; Thresh and Owusu 1986; Thresh et al. 1988).

Corresponding author: O. Domfeh; E-mail: kofdomfeh@gmail.com

Accepted for publication 2 May 2016.

http://dx.doi.org/10.1094/PDIS-03-16-0404-RE

(C) 2016 The American Phytopathological Society
CSSV reinfection of newly established cacao farms poses a serious threat to the cacao industry (Adegbola 1977; Ampofo and OseiBonsu 1988; Legg et al. 1981) and this usually begins from the outer rows closest to the source of infection (Ollennu et al. 1989). However, this important epidemiological information is usually not taken into account by famers during establishment of new farms (DzahiniObiatey et al. 2006; Ollennu et al. 1989). Based on work done in Nigeria, a recommendation was made that new plantings in areas where CSSVD is endemic should end at least $10 \mathrm{~m}$ away from existing cacao establishments (Are 1969). This recommendation was subsequently endorsed for implementation in Ghana (Ollennu et al. 1989). However, Ghanaian farmers have been reluctant to practice this recommendation, especially when the land to be left unused forms a large proportion of the available land (Dzahini-Obiatey et al. 2006; Ollennu et al. 1989).

Inspired by earlier studies on the merits of interplanting cacao with nonhost (immune) crops (Cornwell 1958; Thresh 1958; Vanderplank 1948) and the determination to enhance adoption of the 10-m cacaofree zone around entire plantings, this study was conducted to evaluate the effectiveness of using citrus, oil palm, and kola as barrier crops to reduce the spread of CSSVD from old establishments into new plantings. Preliminary results of this trial, based on data collected over a 5-year period post CSSV 1A inoculation, indicated that oil palm and citrus were the most effective in protecting test plants from CSSV infection and also provided evidence of the profitability of growing such crops as a barrier in comparison with cacao (Ollennu et al. 2005). In the current article, we present the overall assessment of this trial based on data covering the entire duration of the trial ( 7 years post CSSV 1A inoculation) and discuss factors likely to affect the adoption of this recommendation.

\section{Materials and Methods}

The trial was established at the Bunso $\left(6^{\circ} 17^{\prime} 21.037^{\prime \prime} \mathrm{N}, 0^{\circ} 28^{\prime}\right.$ $4.548^{\prime \prime}$ W) substation of the Cocoa Research Institute of Ghana (CRIG) in 1992 (Ollennu et al. 1992). Hybrid cacao pods obtained from hand-pollinated flowers were sown in humus-rich soil in individual polythene bags ( 7 by $10 \mathrm{~cm}$ ) in a nursery and kept up to 6 months prior to planting in the field. The cacao seedlings were transplanted into the field in May to June 1992, together with the barrier crops. The treatments were arranged in a randomized complete block design with three replicates. Two rows of kola, citrus ('Late 
Valencia'), and oil palm spaced at $8.8 \mathrm{~m}$ (triangular), $5.5 \mathrm{~m}$ (square), and $8.8 \mathrm{~m}$ (triangular), respectively, were planted in cordons to serve as barrier crops (Fig. 1). The control consisted of three rows of cacao planted at 3 by $3 \mathrm{~m}$ (Fig. 1). The kola, oil palm, citrus, and cacao barriers surrounded a core of 25 cacao plants (hereafter referred to as source plants) which were inoculated with the New Juabeng strain of CSSV (CSSV 1A) 5 years after establishment through patch grafting (Legg et al. 1980). Incidence of CSSV symptoms was recorded through monthly visual inspections in 174 noninoculated cacao trees per replication (hereafter referred to as test plants) surrounding each barrier. In the case of the cacao (control) treatment, the cacao plants in the barrier itself were also inspected for CSSV symptoms. At each inspection, cacao trees showing symptoms of CSSVD were promptly removed to prevent the spread of infection from cacao trees other than those inoculated. In order not to influence vector population dynamics, no insecticide application was made; however, local cultural practices appropriate for cacao production were carried out.

Economic data collection and evaluation. Economic analysis of the different treatments was conducted using partial budget analysis (CIMMYT 1988). The analysis entailed the quantification and valuation of outputs (crop yields) and inputs (labor, agrochemicals, and equipment) used in the establishment and maintenance of the various treatments. Yield and input costs of cacao and the barrier crops were collected monthly and the cumulative numbers computed for each year. The total revenue from each treatment was estimated using the prevailing market price of the crops and averaged across years. The total cost incurred for each treatment was the summation of all the costs of inputs used for that treatment averaged across years. The net benefit (a measure of profitability) for each treatment was obtained as the difference between the total revenue and the total cost. In the evaluation, a positive net benefit indicated that the treatment was profitable while a negative value implied otherwise. Another measure of profitability, the benefit-cost ratio (BCR), was derived by dividing the total revenue by the total cost of the corresponding treatments. A BCR of $>1$ was regarded as profitable, $<1$ as not profitable, and 1 as a break-even point.

Statistical analysis. The time to manifestation of CSSVD symptoms was an interval-censored datum because, between years, the exact time that individual trees got infected was unknown and some trees were not visibly infected within the period of the study. Therefore, the data were summarized using survival curves for the conditions being studied. A log-rank test was used to assess the null hypothesis of no differences among the survival curves. As a followup, multiple comparisons of treatments using a Wilcoxon test with Tukey-Kramer adjustment was used to determine differences among treatments. The Tukey-Kramer adjustment controls the type I error rate due to multiple testing. All tests were run using Proc LIFETEST in SAS software (SAS Institute Inc. 2013).

\section{Results}

The first appearance of CSSVD symptoms occurred 2 years after the inoculation of source plants with CSSV 1A and this involved seven trees; three within the cacao barrier; three across the kola barrier, and one across the oil palm barrier (Table 1). The highest incidence of CSSVD symptoms occurred in 2004, with 120 occurring in the cacao treatment while 32 were found in the kola treatment (Table 1). Across years, CSSVD spread in the cacao treatment tended to occur in trees close to each other, progressing from the source into the test plants (an indication of "radial" spread) whereas, in kola and oil palm treatments, symptoms were scattered. Across the citrus and oil palm barriers, only 1 and 5 test trees, respectively, out of 522 trees showed symptoms of CSSVD throughout the trial period (Tables 1 and 2). Survival rates of 99.81 and $99.04 \%$ were obtained among test trees in the citrus and oil palm treatments, respectively (Table 2). Of 522 test trees, 89 showed symptoms of CSSVD in the kola treatment (survival rate of $82.95 \%$ ) while 134 visibly infected test trees were found across the cacao barrier (survival rate of $74.33 \%$ ) (Table 2).
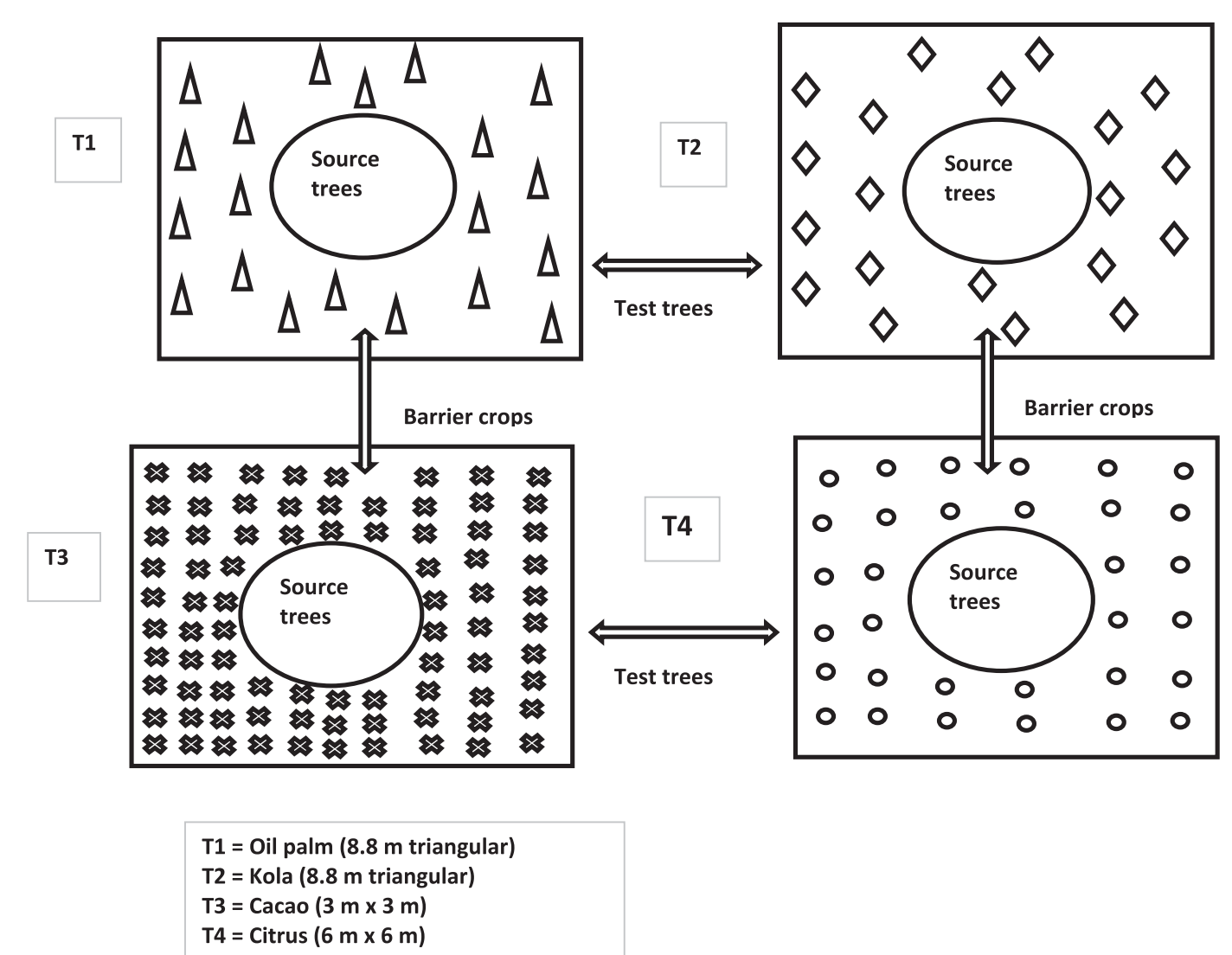

Fig. 1. Diagrammatic presentation of experimental lay-out of the barrier cropping trial (one block) set up to evaluate the effectiveness of oil palm, kola, and citrus in protecting new cacao plantings against cacao swollen shoot virus disease spread. Cacao was included to serve as control. 
A cumulative number of 141 trees showed symptoms of CSSVD among cacao trees within the barrier itself, bringing the total number of symptomatic infections occurring in the cacao (control) treatment to 275. The survival rates of citrus and oil palm treatments were identical and highest, followed by the kola treatment, while the cacao treatment had the lowest (Fig. 2). The log-rank test performed to test

Table 1. Cumulative data on cacao swollen shoot virus disease (CSSVD) spread in cacao, cola, oil palm, and citrus treatments from 1998 to 2004

\begin{tabular}{lcccc}
\hline & \multicolumn{4}{c}{ Barrier crop } \\
\cline { 2 - 5 } Year & Cacao $^{\mathbf{a}}$ & Kola & Oil palm & Citrus \\
\hline 1998 & 0 & 0 & 0 & 0 \\
1999 & 3 & 3 & 1 & 0 \\
2000 & 2 & 2 & 0 & 0 \\
2001 & 13 & 6 & 0 & 0 \\
2002 & 49 & 19 & 0 & 0 \\
2003 & 88 & 27 & 4 & 1 \\
2004 & 120 & 32 & 0 & 0 \\
Total $^{\text {b }}$ & 275 & 89 & 5 & 1 \\
\hline
\end{tabular}

a Includes visibly infected cacao trees within the cacao barrier.

b Total number of trees with CSSVD symptoms.

Table 2. Data on four barrier crops evaluated over an 8-year period following inoculation of inner core trees with the Cacao swollen shoot virus ${ }^{\mathrm{a}}$

\begin{tabular}{lccc}
\hline Treatments & ${\text { Test plants }(\boldsymbol{n})^{\mathbf{b}}}$ & ${\text { Affected plants }(\boldsymbol{n})^{\mathbf{c}}}$ & ${\text { Surviving trees }(\boldsymbol{\%})^{\mathbf{d}}}^{\text {S }}$ \\
\hline Citrus & 522 & 1 & 99.81 \\
Cacao & 522 & 134 & 74.33 \\
Kola & 522 & 89 & 82.95 \\
Oil palm & 522 & 5 & 99.04 \\
Total & 2,088 & 229 & 89.03 \\
\hline
\end{tabular}

${ }^{a}$ Results are aggregate values over the three plots in the study.

$\mathrm{b}$ Total number of test plants per treatment.

c Number of disease-affected test plants.

$\mathrm{d}$ Percentage of cocoa trees surviving. the hypothesis of equal survival curves was found to be significant $(P<0.0001)$. This pattern of differences in the survival curves was confirmed based on a Wilcoxon test with Tukey-Kramer adjustment (Table 3).

The mean labor input for all field operations was highest for the cacao barrier and lowest for the kola barrier (Table 4). The mean yield estimates was highest for the oil palm barrier and lowest for the kola barrier (Table 4). The BCR of 9.0, 23.2, and 10.3 for oil palm, citrus, and kola, respectively, were higher than that obtained from cacao (4.7) (Table 4), implying that all the barrier crops used in this study were more profitable than cacao.

\section{Discussion}

This article presents results from a 12-year field study carried out to investigate the effectiveness of using three CSSV nonhost crops as barrier to prevent spread of CSSVD in newly established cacao farms caused by inoculum from existing cacao trees. A preliminary report on this study covering a 5-year period post CSSV 1 A inoculation was published by Ollennu et al. (2005). Results obtained in subsequent years of the trial further affirm the findings and conclusions of the preliminary report because no significant change occurred in the trend of CSSVD spread or in economic indicators.

Seven years after introducing CSSV 1A into the source plants serving as infectors, only one visibly infected tree was found in the treatment using citrus as a barrier, while five symptomatic trees were found in the oil palm treatment. In contrast, significantly higher number of trees showed symptoms of CSSVD in the cacao (control) and kola treatments. Therefore, the citrus and oil palm barriers have been proven to be the most effective in preventing CSSVD spread among the test plants.

The mode of transmission of CSSV by the mealybug vector has been described as semipersistent, with no virus replication within the mealybug (Roivainen 1976). Mealybugs lose their ability to transmit CSSV if they do not come into contact with another infected plant within $48 \mathrm{~h}$ after acquiring the virus (Ollennu et al. 1992; Roivainen 1976). This suggests that CSSV is probably stylet borne and not circulative. Based on this knowledge, it was hypothesized that virus-carrying mealybugs may not be able to infect new establishments

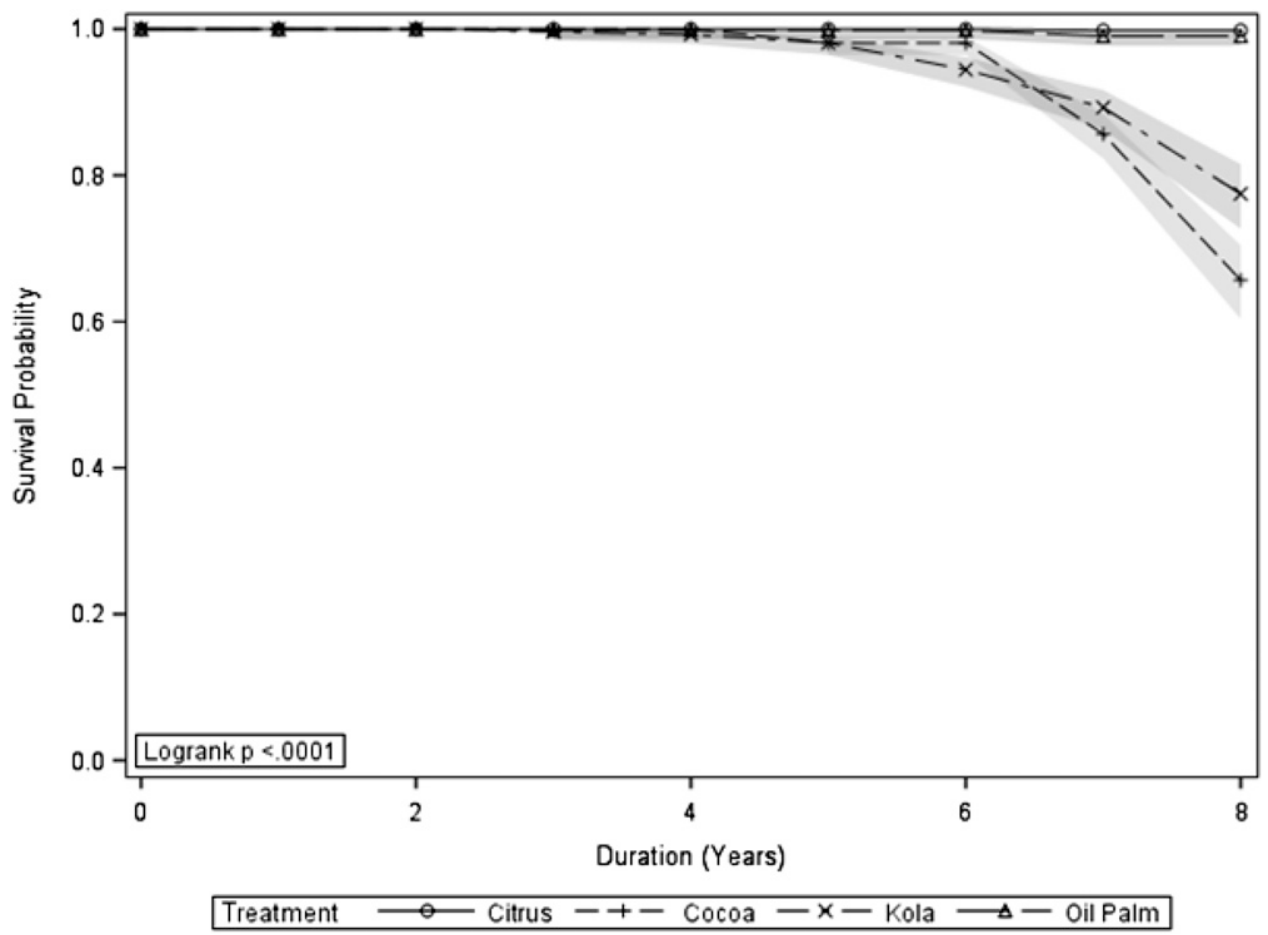

Fig. 2. Tree survival probability curves of four barrier crops evaluated over a 7-year period following inoculation of inner core trees with the Cacao swollen shoot virus (CSSV). Shaded envelopes on each curve are the $95 \%$ confidence bands on the survival probabilities. 
surrounded by a CSSV nonhost (immune) barrier crop because the mealybugs may lose the virus by the time they move through the barrier. This is premised on the fact that mealybugs move slowly and are unlikely to be able to cross the barrier within $48 \mathrm{~h}$, and they have no further access to the virus because the barrier crops are CSSV immune. This could partly explain why many symptomatic trees were found in the treatment using cacao (which is host to CSSV) as a barrier compared with the citrus, oil palm, and kola treatments. In the cacao treatment, CSSVD symptoms were first found in cacao trees closest to the source plants and progressed through the barrier into the test plants, a finding consistent with that of Ollennu et al. (1989) and Thresh et al. (1988). In a recent field trial initiated at CRIG, an attempt was made to determine the optimum number of outer rows of cacao that should be inoculated with a mild CSSV strain for effective cross-protection of the entire cacao crop in a farm against the effects of the severe CSSV 1A strain. Apart from benefits to be gained from limiting mild strain inoculation only to the outer rows, the inoculated outer rows are also expected to serve as a barrier to slow down the spread of the severe strain of CSSV into the inner crop. Preliminary results of this trial show that the spread of severe CSSV 1A follows a gradient, with incidence decreasing as distance from the source of infection increases (O. Domfeh, unpublished). These examples provide further evidence of the risk involved in planting cacao very close to infected cacao farms, and emphasize the need for a cacao-free cordon around new establishments.

However, a cacao free-cordon around new establishments will not be effective in the case of jump CSSV spread, an instance where virus-carrying mealybugs are blown by the wind to a location far from the source of infection. This route has been recognized as a means of CSSV spread (Cornwell 1960; Strickland 1950). One of the reasons for assessing the effectiveness of citrus, kola, and oil palm as barrier crops was that they should be able to form a windbreak and prevent jump CSSV spread into the young cacao (Ollennu et al. 2005). Kola was very slow in establishing, causing the cacao to outgrow it. This might have allowed windblown mealybug nymphs to cross to the adjacent cacao (Ollennu et al. 2005) and could be the main reason why a relatively high number of infections occurred in this treatment. In a field trial at CRIG to assess the tolerance of 15 cacao progenies to CSSV, Ollennu et al. (2002) planted two rows of kola between CSSV-inoculated treatments and the noninoculated

Table 3. Pairwise comparisons of survival curves for the four treatments based on Wilcoxon test with Tukey-Kramer adjusted $P$ values

\begin{tabular}{lc}
\hline Treatment comparisons & $\boldsymbol{P}$ value (Tukey-Kramer adjusted) \\
\hline Citrus versus cacao & $<0.0001$ \\
Citrus versus kola & $<0.0001$ \\
Citrus versus oil Palm & 0.9766 \\
Cacao versus kola & $<0.0001$ \\
Cacao versus oil palm & $<0.0001$ \\
Kola versus oil palm & $<0.0001$ \\
\hline
\end{tabular}

Table 4. Summary of economic analysis of four barrier crops (1992 to 2004) ${ }^{\mathrm{a}}$

\begin{tabular}{lcccc}
\hline & \multicolumn{4}{c}{ Barrier crops (treatments) } \\
\cline { 2 - 5 } Economic indicator & Cacao & Oil palm & Citrus & Kola \\
\hline Labor input (person days/ha) & 93.1 & 57.2 & 33.9 & 31.9 \\
Yield (kg/ha) & 762.1 & $4,700.5$ & $3,147.2$ & 254.6 \\
Total Cost (GH $\phi / h a)$ & 54.39 & 53.85 & 35.45 & 27.56 \\
Total Revenue $(\mathrm{GH} \phi / \mathrm{ha})$ & 257.47 & 486.77 & 823.32 & 284.12 \\
Net Benefit $(\mathrm{GH} \phi / \mathrm{ha})$ & 203.1 & 432.9 & 787.9 & 256.6 \\
Benefit-cost ratio & 4.7 & 9.0 & 23.2 & 10.3 \\
\hline
\end{tabular}

a Yield and input costs of cocoa and the barrier crops were collected monthly and the cumulative numbers computed for each year. The total revenue from each treatment was estimated using prevailing market price of the crops and averaged across years. The total cost incurred for each treatment was the summation of all the costs of inputs used for that treatment averaged across years. control. The kola could not establish well and, as a result, CSSV spread into the control treatment, resulting in the discontinuation of the trial. It has been recommended that, if kola is to be used as a barrier crop, it should be established at least 2 years prior to planting cacao (Ollennu et al. 2005). To offset the problem of slow establishment, vegetatively propagated kola rather than seedlings could be used in establishing the kola barrier because the former has been demonstrated to result in quicker establishment (Dadzie et al. 2013).

Although not significantly different from the oil palm treatment statistically, the citrus treatment was the most effective. Apart from the factors discussed, the citrus crop has an added advantage of being a host of a variety of mealybug species, including $P$. citri Risso, one of the two most important mealybug vectors of CSSV in Ghana (Box 1945; Campbell 1990; Ollennu et al. 2005; Posnette 1950). Therefore, it is likely that mealybugs were attracted more to and probably spent longer time on the citrus crop than the others, leading to viruliferous mealybugs losing their ability to transmit CSSV into the adjacent cacao. This assertion is partly supported by the relatively high number of mealybugs occasionally observed on the citrus crop during the trial. This might explain why only one tree was found with CSSVD symptoms in the citrus treatment.

In this study, we did not investigate the potential of oil palm attracting rodents when used as a barrier crop. Some farmers who have oil palm trees around their cacao farms have observed higher incidences of rodent-associated destruction of pods on such farms (G. A. Ameyaw, personal communication). This observation and its impact on the adoption of oil palm as a barrier crop need investigation.

Results obtained from the economic analyses performed on the different crops suggest that planting citrus, oil palm, or kola as barrier crops could adequately compensate for the area they occupied because their levels of profitability were comparable with that of cacao. This indicates that farmers will not lose revenue if they plant any of the crops in the 10-m cacao-free cordon recommended in Nigeria (Are 1969) and proposed in Ghana by Ollennu et al. (1989).

Previous authors have repeatedly indicated that the spread of CSSVD is likely to be decreased by interplanting cacao with CSSVDimmune crops to intercept inoculum, provide increased separation, and restrict vector movement (Cornwell 1958; Thresh 1958; Vanderplank 1948). Results of this study provide ample evidence of the effectiveness of barrier cropping with CSSVD-immune crops.

Most cacao farms in Ghana are small in size and have irregular boundaries (Dzahini-Obiatey et al. 2006; Ollennu et al. 1989; Thresh et al. 1988). Planting barrier crops around such farms will not be feasible. Consequently, Owusu and Ollennu (1997) proposed pooling of individual small land holdings in order to plant in large blocks. The setting up of land banks into which individuals, families, and other landowners could be encouraged to release their lands for specific projects has also been proposed (Dzahini-Obiatey et al. 2006).

\section{Conclusion}

The overall results obtained from this trial provide evidence that the citrus and oil palm barriers are the most effective in protecting new cacao establishments from CSSVD spread originating from adjacent old cacao. The results also indicate that the barrier crops can generate income that would adequately compensate for the cocoafree zone. In this study, kola was found to be less effective as a barrier crop but, in experiments elsewhere, kola and coffee have been found to be effective. To enhance adoption of barrier cropping, it would be important to, among other things, set up demonstration farms on farmers' fields across all cacao-growing regions where CSSVD is endemic. In this study, disease assessment was done through visual inspection and, as such, the actual CSSV incidence in the different treatments may be higher than what we reported due to the possibility of latent infections. Serological- or nucleic acid-based techniques should be employed in future studies to test virus presence in symptomatic as well as asymptomatic test plants.

\section{Acknowledgments}

We thank K. Johnson (of blessed memory) and H. Oboom for providing technical support; and C. Doetkott, a consulting statistician at the Information 
Technology Services, North Dakota State University, for analyzing the CSSV data. This manuscript (CRIG/05/2016/040/002) is published with the kind permission of the Executive Director of CRIG.

\section{Literature Cited}

Adegbola, M. O. K. 1977. Rehabilitating cocoa swollen shoot virus infected farms: The Offa-Igbo experience. Pages 182-188 in: Proc. 5th Int. Cocoa Res. Conf. Ibadan, Nigeria. Cocoa Research Institute, Cocoa Producers' Alliance, Ibadan, Nigeria.

Ameyaw, G. A., Dzahini-Obiatey, H. K., and Domfeh, O. 2014. Perspectives on cocoa swollen shoot virus disease (CSSVD) management in Ghana. Crop Prot. 65:64-70.

Ampofo, S. T., and Osei-Bonsu, K. 1988. Models for rehabilitating small scale cocoa farms in Ghana. Pages 51-55 in: Proc. 10th Int. Cocoa Res. Conf. San Domingo, Dominican Republic.

Are, L. A. 1969. Rehabilitation of cocoa farms. Cocoa Grow. Bull. 13:11-13.

Bigger, M. 1981. The relative abundance of the mealybug vectors (Hemiptera: Coccidae and Pseudococcidae) of cocoa swollen shoot disease in Ghana. Bull. Entomol. Res. 71:435-448.

Box, H. E. 1945. Insect transmission of the swollen shoot virus in West African Cocoa. Nature 155:608-609.

Campbell, C. A. M. 1983. The assessment of mealybugs (Pseudococcidae) and other Homoptera on mature cocoa trees in Ghana. Bull. Entomol. Res. 73:137-151.

Campbell, C. A. M. 1990. The susceptibility of cocoa to mealybugs and other honey dew-producing Homoptera in Ghana. Bull. Entomol. Res. 80:137-151.

CIMMYT. 1988. Page 79 in: From Agronomic Data to Farmer Recommendation: An Economic Manual. CIMMYT (International Maize and Wheat Improvement Center), Mexico, DF

Cornwell, P. B. 1958. Movements of the vectors of virus diseases of cacao in Ghana. I. Canopy movement in and between trees. Bull. Entomol. Res. 49:613-630.

Cornwell, P. B. 1960. Movement of vectors of virus disease of cacao in Ghana. II. Wind movement and aerial dispersal. Bull. Entomol. Res. 51:175-201.

Crowdy, S. H., and Posnette, A. F. 1947. Virus diseases of cacao in West Africa II. Cross immunity experiments with viruses 1A, 1B and 1C. Ann. Appl. Biol. 34:403-411.

Dadzie, M. A., Opoku, S. Y., Akpertey, A., Akrofi, A. Y., Lowor, S., Assuah, M. K., and Amoah, F. M. 2013. Kola cultivation in Ghana. Tech. Bull. Cocoa Res. Inst. Ghana No. 26.

Dzahini-Obiatey, H., Ameyaw, G. A., and Ollennu, L. A. A. 2006. Control of Cacao swollen shoot virus (CSSV) disease by eradicating infected trees in Ghana: A survey of treated and replanted areas. Crop Prot. 25:647-652.

Legg, G. T., Owusu, G. K., Ollennu, L. A. A., and Lovi, N. K. 1981. The problems of controlling cocoa swollen shoot disease in Ghana. Pages 267-278 in: Proc. 6th Int. Cocoa Res. Conf. Cocoa Producers Alliance, Caracas, Venezuela.

Legg, J. T., Kenten, R. H., and Lockwood, G. 1980. Tolerance trials with young cocoa trees infected with Cacao swollen shoot virus. Ann. Appl. Biol. 95:197-207.
Ollennu, L. A. A., Osei-Bonsu, K., Acheampong, K., and Aneani, F. 2002. Barrier cropping trial. Page 139 in: Annual Report, 2001/2002. Cocoa Research Institute, New Tafo-Akim, Ghana.

Ollennu, L. A. A., Osei-Bonsu, K., Acheampong, K., and Aneani, F. 2005 Preliminary studies of the control of cocoa swollen shoot disease by the use of immune crops as barrier. Pages 839-843 in: Proc. 14th Int. Cocoa Res. Conf. Cocoa Producers' Alliance, Accra, Ghana.

Ollennu, L. A. A., Osei-Bonsu, K., Jones, A. and Acheampong, K. 1992. The use of CSSV immune crops as barrier between cocoa plantings. Pages 71-72 in: Annual Report, 1992/1993. Cocoa Research Institute, New Tafo-Akim, Ghana.

Ollennu, L. A. A., Owusu, G. K., and Thresh, J. M. 1989. Spread of cocoa swollen shoot virus to recent plantings in Ghana. Crop Prot. 8:251-264.

Owusu, G. K. 1983. The cocoa swollen shoot virus problem in Ghana. Pages 73-83 in: Plant Virus Epidemiology. R. T. Plumb and J. M. Thresh, eds. Blackwell Scientific Publications, Oxford.

Owusu, G. K., and Ollennu, L. A. A. 1997. The problem of the re-infection of replanted cocoa by cocoa swollen virus in Ghana. Pages 179-188 in: Proc.1st Int. Cocoa Pest Dis. Semin. Novotel, Accra, Ghana.

Owusu, G. K., Ollennu, L. A. A., and Dzahini-Obiatey, H. 1996. The prospect of mild strain cross-protection to control cocoa swollen shoot disease in Ghana. Pages 121-127 in: Proc. 12th Int. Cocoa Res. Conf. Cocoa Producers' Alliance, Salvador, Brazil.

Posnette, A. F. 1943. The diagnosis of swollen shoot disease of cacao. Trop. Agric. Trinidad 21:156-158.

Posnette, A. F. 1950. Virus disease of cocoa in West Africa, VII. Virus transmission by different vector species. Ann. Appl. Biol. 37:378-384.

Posnette, A. F. 1951. Virus research at the West African Cacao Research Institute, Tafo, Gold Coast. Trop. Agric. (Trinidad) 28:133-142.

Roivainen, O. 1976. Transmission of cocoa viruses by mealybugs (Homoptera: Pseudococcidae). J. Sci. Agric. Soc. Finl. 48:203-204.

SAS Institute Inc. 2013. SAS/STAT® 13.1 User's Guide. SAS Institute Inc., Cary, NC.

Steven, W. F. 1936. Swollen shoot and die-back-A new disease of cocoa. Gold Coast Farmer 5:144.

Strickland, A. H. 1950. The dispersal of Pseudococcidae (Hemiptera: Homoptera) by air currents in the Gold Coast. Proc. R. Entomol. Soc. London 25:1-9.

Thresh, J. M. 1958. Control of cacao swollen shoots disease in West Africa. Pages 1-36 in: Tech. Bull. W. Afr. Cocoa Res. Inst. No. 4.

Thresh, J. M., and Owusu, G. K. 1986. The control of cocoa swollen shoot disease in Ghana: An evaluation of eradication procedures. Crop Prot. 5:41-52.

Thresh, J. M., Owusu, G. K., Boamah, A., and Lockwood, G. 1988. Ghanaian cocoa varieties and swollen shoot virus. Crop Prot. 7:219-231.

Vanderplank, J. E. 1948. The relation between the size of fields and the spread of plant-disease into them. Part I Crowd diseases. Emp. J. Exp. Agric. 16:134-142. 